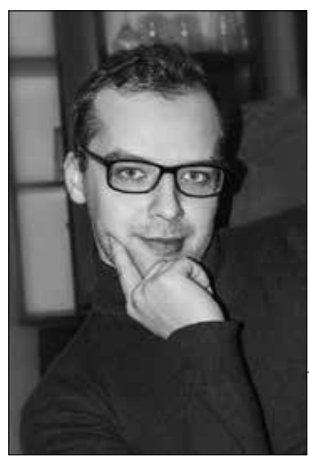

https://doi.org/10.24101/logos.2017.38

Gauta 20170218

RAMŪNAS B. MALCIUS

Vilniaus universitetas, Lietuva

Vilnius University, Lithuania

\title{
PAMATINIŲ ONTOLOGINIŲ SĄVOKŲ IŠSKLAIDA
}

\section{The Unfolding of the Fundamental Ontological Notions}

\author{
SUMMARY
}

The basic fundamental ontological notions "Being" , "being" and "a being“ compose a triple ontological difference. By unfolding the dual (being and a being) ontological difference, one more term (Being) must be also unfolded. By using Thomistic philosophy, it becomes clear, that the notion of "Being" must be perceived as God. The notion of "being" in this work is understand as a transcendental. By referring to Kant's understanding of the transcendentals, and Heidegger's analysis of the meaning of being (Sein), I approach the thesis that being (Sein) is the condition and the ground of a being. The unfolding of the notion ",a being" shows that a being is a creature. That, which is not-God and not-being, must be named as a being. Because God exist by necessity, every being is contingent.

\section{SANTRAUKA}

Pamatinės ontologinės sąvokos "būtis", "buvimas" ir "būvinys" sudaro trinarę ontologinę skirti. Išplečiant dvinarę (buvimo ir būvinio) ontologinę skirtị trečiu (būties) nariu, būtina iškleisti šias sąvokas. Remiantis tomizmu paaiškejja, kad būtis turi būti suprasta kaip Dievas. Sąvoka "buvimas“ šiame darbe suprantama kaip transcendentalija. Remiantis Kanto transcendentalumo samprata ir Heideggerio buvimo prasmės analize, prieinama išvada, kad buvimas yra būvinio sąlyga ir pagrindas. „Būvinio“ sąvokos iškleidimas parodo, kad būvinys yra kūrinys. Tai, kas yra ne-Dievas ir ne-buvimas, turi būti pavadinta "būviniu“. Dèl to, kad tik Dievas egzistuoja būtinai, visi būviniai yra kontingentiški.

\section{IVADAS}

Norint atsakyti ì klausimą „kas yra tị tarp būvinio ir buvimo. Be šios skirties buvimas?", reikia daryti ontologinę skir- buvimo klausimas negalètų būti net ke- 
liamas, kadangi visados būtų užklausiamas ne buvimas, o pats būvinys. Tačiau ir šios skirties nepakanka. Nagrinejjant buvimo ir būvinio problematika, į ontologinę skirti reikia įtraukti ir trečią nari būtí. Tai padarant, dvinarè ontologinè skirtis tampa trinare.

Atlikti tokị žingsnị iš dalies paskatina lietuvių kalba. Kadangi lietuvių kalboje sąvokos "būtis", "buvimas" ir "būvinys" dažnai vartojamos sinonimiškai (ypač sąvokos "būtis" ir būvinys"), tai iškelia klausimą: ar tikrai šios sąvokos yra identiškos? Kad „būties“ sąvoka yra miglota, tai jau buvo aišku ir Platonui ${ }^{1}$. Tačiau dar didesnis neaiškumas atsiranda tuomet, kada turime tris tos pačios šaknies sąvokas: „būtis", "buvimas" ir "būvinys".
Minètosios sąvokos šiame darbe suprantamos kaip pamatinès ontologinès sąvokos. Pasakymas „pamatinès sąvokos" nurodo, kad ontologijoje yra tokiu sąvokų, kurių turinys grindžia visą tolesnę filosofiją kaip ontologiją. Nenurodant, ką šios sąvokos „slepia“ savyje ir jas vartojant kaip savaime suprantamas, būtų galima kelti hipotezę, kad sąvokos „būtis“, „buvimas" ir „būvinys" vartojamos tik kalbose ir nuomonèse, todèl nurodyti, ką jos turi reikšti, visai nèra reikalo². Tačiau jeigu taip būtų daroma, ontologija prarastų pamatą - neturèdami aiškaus šių sąvokų apibrèžimo ir supratimo, ontologines problemas nagrinètume net nesupratę, kas yra tai, ką nagrinèjame.

\section{DIEVAS KAIP BÜTIS}

\section{Tomistinès nuostatos Dievo klausimu}

Turbūt svarbiausiu filosofu, kuriuo remiantis galima Dievą tapatinti su Būtimi, o ne būviniu ar buvimu, yra Tomas Akvinietis. Tomistinès perskyros tarp essentia ir esse, tarp Ipsum Esse ir habens esse, tarp ens ir esse būtent ir leidžia tai padaryti. Etiennas Gilsonas, bandydamas nusakyti Akviniečio Dievo sampratos esmę, teigia, kad „esmè ir būtis Dieve yra tas pat. Galima sakyti, jog Dievas yra „,būtis-prie-kurios-nieko-nebegalimapridèti“" (being-that-has-nothing-added-toit) ir kuris yra būtent toks dèl to, kad jo esmè užkerta bet kokią galimybę ką nors pridèti. Kadangi prie tokios būties negalima pridèti nieko, tokia būtis nepriklau- so nuo jokios determinacijos; pagal apibrěžimą tokia būtis taip pat yra begalinè, grynas aktas. <..> Dievas taip pat yra visiškai užbaigtas, laisviausias nuo bet kokiu materijos determinacijų; taip pat būtis yra aukščiausio nematerialumo laipsnio. Taip pat Dievas yra aukščiausias tobulumo laipsnis" (Gilson 1960: 166-167). Žinoma, Gilsono pateiktame Akviniečio Dievo sampratos apibendrinime svarbiausias pastaba apie Dievą yra ta, kad Dievas yra Būtis. Kadangi Dievas yra Ipsum Esse, tarp Dievo ir sąvokos „Būtis“ galima dèti lygybės ženklą. Tačiau prieiti tokią išvadą galima tik aptarus esmès ir buvimo klausimą Dievo atžvilgiu bei Dievo santykị su būviniais kaip habens esse. 


\section{Esmè ir buvimas}

(Dievo būtinumo klausimas)

Nors Dievas, kaip teigia Gilsonas, Šventajame Rašte yra suprantamas kaip buvinys, tačiau Dievo laikymas buviniu kelia abejonę. Kadangi Dievas yra priešingas buviniui, reikia sakyti, kad Dievas yra Būtis. Kaip Gilsonas sako:

Dievas yra būvinys. Taip sako Šventasis Raštas, arba bent jau teigiama, kad Šventajame Rašte taip sakoma. Jei Dievas yra Tas Kuris Yra, jo esse yra jo esmè; ir, kaip kiekvienas būvinys yra savo esmèj egzistuojantis, būvinio sąvoka nèra tinkama Dievui. Kaip Platono Gẻris, Dievas privalo būti pastatomas už būviniú; causa prima est supra est (Gilson 1993: 33).

Kadangi savo esme visi būviniai yra kontingentiški (jų egzistavimas nèra būtinas), tai iš karto iškyla du klausimai: 1. Ar Dievas egzistuoja su būtinumu? 2. Kas yra Dievo esmé (essentia)? Atsakant i pirmą klausimą galima teigti, kad Dievas egzistuoja su būtinumu, kadangi visa, kas yra ne-Dievas, yra kontingentiška, nes, kaip sako Kuraitis, „sutvèrimai ne su būtinumu egzistuoja, ju egzistavimas pareina ne iš ju esmès, o iš kito" (Kuraitis 1931: 107). Kitaip sakant, visame, kas nèra Dievas, egzistencija yra neprivaloma, kadangi egzistavimas nèra jų esmè. Patys nebūdami savo paties priežastimi, visi būviniai yra kontingentiški. Tačiau Dievas, suvokiamas ne kaip būvinys, o kaip Būtis, turi egzistuoti būtinai, kadangi šioje vietoje Dievas yra suprantamas kaip tas, kuris visam kam suteikia buvimą. Vadinasi, Dievas šioje vietoje primena Aristotelio Nejudanti Judintoja, kadangi Dievas suprantamas kaip būvinio egzistavimo priežastis, o Nejudantis Judintojas Aristoteliui yra kitimo priežastis ${ }^{3}$.

Tačiau Dievo egzistavimo būtinumo pripažinimas kyla iš prielaidos, kad turi būti tas, kieno buvimas yra būtinas, būtinumą šioje vietoje suprantant kaip tai, kas tam ar kitam dalykui yra esminga ${ }^{4}$. Kadangi būvinių esmè nèra egzistavimas (dèl kontingentiškumo), tai Dievas ir turi būti tas, kur egzistavimas sutampa su esme. Kuraičiui teisingai sakant, kad „Dievas egzistuoja su būtinumu, nes jo esmèje yra egzistavimas, kitaip sakant, Dievuje esme ir egzistavimas yra tas pats“ (Kuraitis 1931: 108), tai tik Dievui esminga yra būtent egzistavimas. Tačiau būtina pažymèti, kad tokia nuostata taip pat implikuoja fakta, jog tik Dievas ir gali būti toks; kadangi, kaip paaiškès skyriuje „Būvinys kaip kūrinys“, galimybè pasakyti, jog būvinys „yra“ atsiranda tik dèl to, kad Dievas yra būvinio priežastis ${ }^{5}$. Tad tik Dievas ir gali būti tuo Vieninteliu, kurio egzistavimas yra esmè, arba kaip sako Kuraitis, „būtis, kurioje esmé yra realiai identiška su egzistavimu turi būti neapribota tobulume ir gali būti tik viena" (ten pat: 113). Kadangi Dievas yra vienas (krikščioniškuoju požiūriu būtent taip yra teigiama), tai tas, kuris yra vienas, turi pasižymèti būtent tuo, kas Jam vieninteliam tik ir galima. Dievo esmę suprantant kaip egzistavima, reikia kelti klausimą: kas Dieve yra egzistavimas? Atsakant į tokị klausimą paaiškètu kuo būvinio egzistencija skiriasi nuo Dievo egzistencijos. Tačiau, kaip pažymi Gilsonas, nors „yra tiesa, kad Dievas egzistuoja, ir mes tai tikrai žinome, bet Dievo atveju mes nežinome, ką veiksma- 
žodis „egzistuoti“ reprezentuoja“ (Gilson 1993: 40). Kitaip sakant, kaip būna Dievas, mes žinoti negalime, o tuo labiau nusakyti tai tiksliai. Kadangi Dievas yra neribotas, nedeterminuotas, bandant nusakyti Dievo egzistavima, Dievo veikimas būtų apibrěžiamas, o apibrèžimas bet kuriuo atveju apribotų tai, kas iš principo yra neapribojama. Todèl Akvinietis yra teisus, kad Dievo esse mums yra nežinoma ${ }^{6}$.

Žinoma, apie Dievą kalbama ir etinèmis, vertybinemis kategorijomis, o tai tarsi ir nusako, kaip Dievas egzistuoja. Jeigu Dievas, pvz., yra Gèris, Tiesa, Meilè, tai Dievo egzistavimas yra geras, teisingas ir mylintis. Tačiau taip apibūdinant Dievą išreiškiamos ne filosofinès, o tikejjimo nuostatos. Kitaip sakant, tik tikejjimas leidžia sakyti, kad Dievas veikia gerai, teisingai ir iš meilès. Tokie religinès patirties teiginiai filosofijos turètu net nedominti. Kaip sako Franas O'Rourke'as, ,"apie religinės patirties Dievą filosofija turi tylèti: apie Dieva, sako Akvinietis, kuri mes žinome kaip Nežinomą" (O’Rourke 1992: 331). Nusakant Dievo egzistavimo pobūdi, ontologijai nèra svarbu, kaip Dievas būna. Buvimo ir esmės tapatybè Dieve šioje vietoje yra svarbiausia, kadangi tai leidžia teigti, kad Dievas yra Esse, nes Dievas, būdamas Tas, prie kurio jau niekas nebegali būti pridèta, ir sukuria toki fakta, nes tai, kas Dieve yra esmè, ir yra pats Dievas.

\section{Dievas kaip Ipsum Esse}

Laikantis tomistinès nuostatos, kad egzistencija ir esmè Dieve sutampa, reikia sakyti, kad Dievas yra Ipsum Esse ${ }^{7}$. Kadangi Esse yra Būtis, tai Dievo „var- das" gali būti pakeičiamas būtent Būtimi. Netgi pati esse sąvoka tomistinejje filosofijoje suprantama kaip kertinè. Marijos Oniščik teigimu, „svarbiausia tomistinès filosofijos sąvoka galima laikyti veiksmažodi esse, dažniausiai vartojamą bendraties forma" (Oniščik 2004: 187). Vadinasi, nagrinëjant sąvoką esse, tuo pačiu patenkama ir i pati tomizmo „,centrą", kadangi šios sąvokos supratimas lemia tiek Dievo, tiek ens kaip habens esse supratimą.

Pasak Gilsono, "sakyti, kad žodis „būtis“ nurodo Dievo esmę ir kad tokia esmè netinka niekam, išskyrus Dievą, yra sakyti, kad Dieve esmè ir egzistencija yra tapačios ir kad tik vieninteliame Dieve esmè ir egzistencija yra tapatu. $<$... Kadangi yra tik vienas Dievas ir šis Dievas yra būtis, o tai sugalvojo ne Platonas, ne Aristotelis, o būtent Mozè, kuris ir sukuria tokią poziciją" (Gilson 1940: 51). Kitaip sakant, prielaida, kad Dievas turi būti suprantamas kaip Būtis, kyla iš Apreiškimo Mozei. Kada Dievas sakosi esąs „Aš Esu, Kuris Esu“ (Iš 3, 14) reiškia, jog Dievo vardas yra Būtis. Dievą suprantant kaip gryną būtí, kaip Tą, kurio esmè yra būtis, nelieka nieko kito, kaip sakyti, kad tai prasmingiausia, ką galima pasakyti apie Dieva, t. y. Dievas ir Būtis yra tas pat. Kaip teigia tas pats Gilsonas, ,jeigu Dievas yra būtis, Jis nèra tik visiškas būvinys: totum esse, bet Jis, tiksliau tariant, yra tikra būtis - verum esse - ir tai reiškia, kad visa kita gali būti tik iš dalies būviniai, sunkiai nusipelnę apskritai būvinio vardo" (ten pat: 64). Vadinasi, Dievui vieninteliam būnant būtimi, joks kitas dalykas negali būti vadinamas būtimi ${ }^{8}$. Todèl pasakymas, kad 
Dievas yra Būtis, pirmiausia turi būti suprastas kaip pasakymas, kad tik Dievas gali būti toks, nes visa, kas yra neDievas, negali būti pats Esse, nes tai yra tik Dievui priskirtinas „vardas“.

Betgi negalima teigti, kad sąvoka esse tomistinèjè filosofijoje turi tik vieną reikšmę t. y. ji nurodo tik Dievą. Pats Akvinietis teigia:

būtis (esse) gali reikšti du dalykus. Tai gali reikšti buvimo aktą (actus essendi) arba tai gali reikšti propozicijų kompozicija, kuri yra paliesta proto, kada protas prijungia predikatą prie subjekto. Suprantant būti pirmaja reikšme, mes negalime žinoti Dievo būties (non possumus scire esse Dei) arba Jo esmès; bet tik antraja prasme. Mes žinome, kad tai yra propozicija, kurią mes suformuojame apie Dieva, kada sakome Dievas yra ir tai yra tiesa, ir tai mes žinome dèl Jo veikimo. ${ }^{9}$

Kitaip sakant, Dievo būtis kaip actus essendi negali būti mums žinoma todèl, kad žmogiškasis protas nèra pajègus suvokti to, kas yra gryna ir prie ko nebegalima nieko kito pridèti, t. y. predikatai Dievui nereikalingi, kadangi jis yra actus purus, kuris neturi jokios potencijos būti dar kažkuo, kuo jis nèra pats. Jau ankstyvame savo tekste Apie esini ir esme Akvinietis sako, kad „esatis, kuri yra Dievas, yra tokio pobūdžio, prie kurios nieko negalima pridèti. Dèl šio savo grynumo jis yra esatis, skirtinga nuo bet kurios kitos esaties" (Akvinietis 2009: 30). Netgi, kaip pripažista Gilsonas, „mes ne tik turètume tvirtinti, kad žmogaus protas yra nepajėgus suvokti Dievą. Tai yra tiesiog per daug akivaizdu, kad tai net būtų verta aiškinti“ (Gilson 1993: 40). Vadinasi, nusakyti Dievo esse negalima dèl to, kad jis ir yra esse. Todèl antru es- se supratimo atveju mes galime žinoti apie Dievą ir sakyti, kad Dievas yra esse, kadangi pats Dievas, apsireikšdamas žmogui (pvz., Mozei), pasisako, kad jis Yra, ir taip žmogus suvokia, jog Dievui netinka predikatas „yra“ dèl to, kad tik Dievas ir yra tas Yra.

Galbūt paradoksalu, bet Dievą suvokiant kaip būti kartu reikia suprasti, kad tai vienintelis prasmingas sakinys, kuriuo tikrai nusakomas Dievas. Dèl to, kad Dievas yra Būtis ir kad Jam egzistencija ir yra esmé, Dievas netelpa (negali būti apibūdinamas) bendrinèmis kategorijomis, kuriomis galima naudotis kalbant apie būvinius. Dèl to pasakymas „Dievui gali būti predikuota būtis" yra bereikšmis, nes Dievas ir yra Būtis; būties kaip predikato priskyrimas Dievui yra neimanomas, nes pats Dievas ir yra būtis. Jeigu Dievas yra Ipsum Esse, tai „būtis" negali būti sąvoka, kurią reikètų laikyti Dievo predikatu, nes tai, kas jau yra jis pats, negali dar būti predikuojama jam pačiam.

\section{Ens ir esse skirtis}

Laikantis tomistinès nuostatos, kad Dievas yra Ipsum Esse, galima teigti, kad Dievas jokiu būdu negali būti suprantamas kaip ens. Kitaip sakant, dèl to, kad ens ir esse sąvokos nurodo skirtingus dalykus, ju tapatinti negalima. Oniščik teigimu, „būtinybė pačioje būties sampratoje skirti ens nuo esse remiasi epistemologine prielaida, jog tai, kas yra pažinu, yra individualūs daiktai, o ne bendras būties principas. Tai, ką galima konceptualizuoti, yra ens - individuali esybè, atskirybe், bet ne esse. Konceptualizavimas siejamas su apibrèžimo gali- 
mybe, t. y. su galimybe atsakyti i klausimą „Kas tai yra?", nurodant esybès esmę“" (Oniščik 2004: 189). Dievui būnant Esse, Jis negali būti ens todèl, kad (1) Dievas yra neapibréžiamas ir (2) Dievas yra bendrybė (Ipsum esse), o ne paskirybė (habens esse).

Aiškinant pirmąją priežasti, kodèl Dievas nèra ens, reikia sakyti, kad Dievas, „netilpdamas“ i bendrines kategorijas, kuriomis būtu galima nusakyti bet kuri būvini (pvz., jo padèti erdvèje, amžių, giminę ir t. t.), negali būti taip apibūdintas. Panašią pastabą pateikia ir Kuraitis, teigdamas, kad „kategorijas savo pagrindu gali turèti tik kontingenčios pasaulio esybès. Dievas yra virš visų kategorijų. Dievo, mat, sąvoka, nėra kokia rūšinė sąvoka. Dievas negali būti suprantamas kaipo priklausąs tokiai ar tokiai realybės rūšiai, kuri skirtųsi giminėmis, ypatybėmis nuo kitų rūšių" (Kuraitis 1933: 80). Kadangi bet koks Dievo apibrèžimas kategorijomis apribotų Dieva, tai Dievas yra tas, ko negalima išsakyti, išsakymą šioje vietoje suprantant kaip galimybę kam nors suteikti apibrèžimą arba kategorizuoti. Todèl Dievui netaikomos nei kategorijos, nei apibrèžimai. O ens kaip tai, kas yra, gali būti išsakyta, kadangi jis nenurodo tik pats savęs ir todèl gali būti apibrèžiamas jo suvokèjo ir taip apibūdinamas bendrinèmis kategorijomis. Tik Dievas nurodo save, kadangi jo essentia yra esse, o tai reiškia, kad Dievas nèra kas nors, kam reikètų pagrindimo. „Dievas, - sako A. Maceina, - yra nepriklausomas nuo būtybès savo būtimi. Jis yra BŪTIS“ (Maceina 1976: 187), o tai reiškia, jog Dievas yra pats sau, ir tai leidžia teigti, jog tik pats Dievas gali tiksliai save nusakyti ir pasakyti, ką jo esmèje reiškia esse.

Aiškinant antrają priežasti, kodèl Dievas nèra ens, reikia teigti, kad Dievas, būdamas Ipsum Esse, negali būti tai, kas turi esse iš kažko kito. Dievui būnant pačia būtimi, visa, kas yra ne-Dievas, yra tas, kas esse gauna iš Dievo. Maceina neklysta, teigdamas, kad „Dievui būtis yra nuosavybė, o žmogui - dovana" (Maceina 1990: 581). Būtina pridurti, kad esse kaip „dovana“ yra ne tik žmogui, bet viskam, kas yra ne-Dievas. Vadinasi, visa, kas yra habens esse, yra ens, išskyrus pati Dievą. Kadangi Dievas suprantamas kaip bendrinis būties principas (nes jis yra pati Būtis), tai niekas kitas negali būti vadinamas taip, kaip ir Dievas. Todèl būtina sakyti, kad ens yra paskirybè, t. y. tai, kas nèra pats iš savęs ir yra kontingentiškas.

\section{BUVIMAS KAIP TRANSCENDENTALIJA}

\section{Dvi transcendentalumo sampratos}

Atlikus būties sąvokos išsklaida, prieita prie išvados, kad Dievas yra Būtis. Dievas, kuris nèra apibūdinamas būviniui galimais predikatais, kuris yra kažkas visiškai priešinga pačiam būviniui ir tam, ką Dievas duoda būviniui. Šioje darbo dalyje bus išskleistas antrasis ontologinès skirties narys - buvimas. Kadangi šiame darbe keliama hipotezė, kad buvimas yra transcendentalija, tai reikia ir aiškesnès transcendentalumo apibrèžties. 
Galimos dvi transcendentalumo sampratos: 1) transcendentalumas gali reikšti galëjimą nusakyti tam tikrus dalykus apie kiekviena būvinį; 2) transcendentalumas gali reikšti salyga, dèl kurios būvinys yra. Pirmoji samprata yra aristotelinè - škotistinè. Kuraičio Ontologijoje teigiama, kad yra penkios transcendentalijos, kurios gali būti pritaikomos kiekvienam būviniui: realybè (res), vienis (unum), šis tas (aliquia), tiesa (verum) ir gèris (bonum). Kartais nurodoma ir šešta transcendentalija - grožis, bet ji yra abejotina, kadangi neaišku, ar apie kiekvieną būvini galima pasakyti, kad jis gražus ${ }^{10}$. Kitaip sakant, ši transcendentalumo samprata nurodo, jog tam tikros sąvokos yra tinkamos kalbant apie kiekvieną būvinįi. Pvz., tokiam būviniui kaip arklys gali būti pritaikoma kiekviena iš minètu transcendentaliju ir nebus padaroma jokia klaida, kadangi paskiras arklys yra realus, vienas, šis tas, tiesa (proto atžvilgiu, nes protas gali ji pažinti) ir geras (arkli pažistančio valios atžvilgiu) ir gražus. Toks transcendentalinis kalbejjimas suprantamas kaip analoginiu sąvoku vartojimo alternatyva, analoginę sąvoką šioje vietoje suprantant kaip tokią sąvoką „kuri yra taikoma dviem ar daugiau daiktu dalinai ta pačia prasme, dalinai skirtinga prasme“ (Kuraitis 1990: 120). Toks analoginis kalbèjimas, dažnas kalbant apie Dievą, kada dalykai, kurie randamai žmoguje (geras, teisingas ir t. t.) yra pritaikomi ir Dievui, su sąlyga, kad Dieve šie žmoguje randami dalykai yra absoliučiai. Tačiau parodžius, kad kalbejjimas apie Dievą yra probleminis ir kad Dieva geriausia suprasti kaip Būtí, toks kalbejimas buvo atmestas, kadangi taip kalbant apie Dieva, Jis tampa dar vienu būviniu.

Vadinasi, pirmoji transcendentalumo samprata taikoma tuomet, kai nusakomi būviniai. Romualdo Grucès teigimu, transcendentalinès sąvokos „,apima visas būčių rūšis, visas padermes, visus būčių skirtumus. Juk ir būtybių skirtumai, dèl kurių vienos būtybės skiriasi nuo kitu, yra realūs dalykai, drauge - ir būtys" (Gruce 1993: 48). Taip suprantant transcendentaluma, galima teigti, kad ir pati "būvinio“ sąvoka yra tam tikra transcendentalija. Kitaip sakant, dèl to, kad transcendentalijos yra tinkamos nusakyti kiekvieną būvini, tai tuo pačiu ir bet kas, kas yra, gali būti vadinamas „būviniu“. Žinoma, Dievui nepritaikoma būvinio sąvoka; nors Dievas yra, bet jo Yra Jam yra esmè. Kad būvinys yra transcendentalija, teigia ir Gilsonas: „gèris, tiesa, vienis jokiu būdu nèra mažiau universalios sąvokos negu būvinio sąvoka, kadangi ten, kur kas nors yra, tuo pačiu yra ir būvinys. Vis dèlto yra kalbama apie būvinį kaip gera, kaip tiesą arba kaip vienį; tačiau niekada nesakoma būvinys kaip būtis, kadangi taip sakyti yra geriausia tik apie Dievą" (Gilson 1960: 144). Todèl būvinys irgi gali būti suprantamas kaip transcendentalija, kadangi visa, kas yra ne-Dievas, yra būviniai ir teisėtai gali būti taip vadinami.

Antroji transcendentalumo samprata yra kantiškoji. Immanuelis Kantas transcendentaliniu vadina „,kiekvieną pažinima, kuriam apskritai labiau rūpi ne objektai, bet būdas, kuriuo mes pažistame objektus, kiek šis būdas turi būti suprantamas a priori“" (Kantas 1982: 69), tad galima teigti, kad transcendentalumas 
jam yra salygos, kurios leidžia pažinti objekta, arba kaip sako Kuraitis, „Kanto filosofijoj transcendentalumas reiškia apriorines bendras pažinimo sąlygas" (Kuraitis 1990: 119). Kantas išskiria dvi trascendentalijas - erdvę ir laiką - kaip sąlygas, kurios mums leidžia ką nors pažinti. Nesant laiko ir erdvès, joks pažinimas nèra i̇manomas, kadangi bet koks objektas (būvinys) visados yra laike ir erdveje. Kitaip sakant, joks būvinys negali būti mąstomas ne-laikiškai ir neerdviškai. Taigi Kantui transcendentalumas yra svarbus tuo, kad jis nurodo sąlygas, kurios leidžia pažinti.

Tačiau Martinas Heideggeris, komentuodamas prieš tai cituotą Kanto minti, teigia, jog „transcendentalinis žinojimas netyrineja būvinio paties savaime, bet greičiau preliminarią buvimo supratimo galimybę, t. y. iš karto ir tuo pačiu - buvimo kaip buvimo konstituciją" (Heidegger 1997: 10). Jeigu Heideggeris neklysta šitaip suprasdamas Kanto minti, tai transcendentalumas gali būti suprastas kaip sąlyga, dèl kurios bet koks būvinys yra. Erdvę ir laiką laikant sąlygomis, kurios leidžia ką nors pažinti, šiame darbe keliama hipotezè, jog laiko ir erdvès neužtenka, kad būtų galima pažinti būvinį. Tam reikia ir buvimo, kuris irgi turi būti suprastas kaip transcendentalija - kaip sąlyga, dèl kurios galima pasakyti, jog buvinys „yra“. Kitaip sakant, jeigu Kantas transcendentalines erdvès ir laiko sąvokas laiko epistemologijos problema, tai buvimas kaip transcendentalinè sąvoka čia suprantamas kaip ontologinè, o tiksliau, pamatinès ontologijos problema, kurią pirmiausia sprendžia Heideggeris. Vadinasi, šiame skyriuje pasiren- kamas antrasis (kantiškasis) transcendentalumo supratimas, svarbiausiu aspektu šioje sampratoje laikant fakta, jog transcendentalija, šiuo atveju buvimas, yra būvinio sąlyga.

\section{Transcendentalinis buvimo klausimo aspektas}

Kadangi, kaip jau minèta, transcendentalija yra ontologine sąlyga, kuri igalina būvinio „yra", buvimas ir turi būti tokia sąlyga. Kitaip sakant, buvimas turi būti pagrindas, kuris garantuoja, jog apie būvini galima pasakyti ką nors prasminga. Heideggerio manymu, „klausimą apie buvimą kaip buvimą galime traktuoti kaip mechanini klausimą apie būvini kaip būvinį. Tada klausimas apie buvimą kaip buvimą taip pat yra transcendentalinis klausimas, tik tiek, kad jis keliamas aukštesniu lygmeniu. Tačiau šitaip reinterpretavus klausimą apie buvimą kaip buvima, kelias i adekvatų jo išskleidimą tampa užvertas. Vis dèlto, toks reinterpretavimas yra pakankamai artimas, juk ir veikale Būtis ir laikas kalbama apie transcendentalini horizonta tačiau tai, kas ten vadinama "transcendentaliniu”, nèra subjektyvios sąmonès transcendentalumas, o priklauso nuo štai-buvimo egzistencialinio-ekstatinio laikiškumo" (Heidegger 2004: 51). Kadangi buvimas suprantamas kaip transcendentalija, o transcendentalija čia žymi sąlyga, tai kartu ieškoma pagrindo, kuris igalina galimybę kalbèti apie būvinius (galbūt netgi apie Dievą).

Ne veltui Heideggeris tiek daug dèmesio skiria ikisokratikams. Buvimui būnant transcendentaline problema, būtent ikisokratinejje filosofijoje ir ieškoma 
to, kas gali galètų būti tokia transcendentalija. Nors Gadameris mano, kad „iš tikrųjų Heideggerio grịžimas nuo Aristotelio physis sąvokos prie ikisokratiniu būties patirties ištakų tebuvo nuotykingas klaidžiojimas" (Gadamer 1999: 201), vis dèlto Heideggeris ši tą randa ikisokratiniuose tekstuose - būtent buvimo kaip buvimo supratimą ar bent jau tokio supratimo užuomazgas. Apibendrindamas ikisokratinị buvimo supratima, Heideggeris teigia, jog "buvimas yra logos, harmonia, aletheia, physis, phainestai, ir tai savaime rodo, kad tai yra bet kas, kas yra nepagrista" (Heidegger 2000: 142). „Nepagristumas" yra svarbi sąvoka. Kadangi buvimas yra kažkas kita negu būvinys ir Dievas, o Dievas, kaip minèta anksčiau, savo esmèje yra pati būtis, vadinasi, Jis pats save ir grindžia, o būvinys yra tai, kas reikalingas sąlygos, kad jis būtú, tai buvimas yra tai, kas yra nepagrindžiama, kitaip sakant, pati sąlyga. Kadangi tai, kas gali būti sąlyga, negali turèti pagrindimo, nes kitaip būtų ieškoma sąlygos sąlygai ir taip toliau, tai buvimas yra tai, kas nereikalingas jokio pagrindimo, nes jis jau yra pagrindas. Toliau tame pačiame tekste, bandydamas aiškinti, ką ikisokratikai vadina buvimu, Heideggeris teigia, jog „buvimas reiškia: stovèjimas šviesoje, pasirodymas, pasirodymas iš paslèpties" (ten pat: 147). Vadinasi, ikisokratikai buvimą supranta kaip sąlyga, kuri leidžia būviniui pa(si)-rodyti; kaip tai, dèl ko būvini galima įvardinti, išsakyti. Todèl ten, kur aptinkamas būvinys, aptinkamas ir buvimas, nes buvimas yra sąlyga, kad būvinys pasirodytu, arba kaip sako O'Rourke'as, „buvimas pasirodo kiekviename patyrime“ (O’Rourke 1992: 309).
Galima spèti, kad ikisokratikai suprato, jog buvimas yra tai, kas yra būvinio „yra" ir jo pasirodymo sąlyga. Buvimą suprantant kaip sąlyga, vadinasi, būvinio pagrinda, galima pritarti Vinco Vyčino minčiai, kad „,būtis, nebūdama būtybè, nèra duotybè, nèra aiškybè, o yra visų duotybių, visų aiškybių pagrindas bei jų atskleidèja" (Vyčinas 2002: 14). Buvimas yra tai, kas yra pagrindas. Todèl buvimo laikymas transcendentalija yra pagristas, kadangi ir Heideggeris pripažista buvimo klausimo transcendentalinę kilmę. Bet vis dèlto verta pažymèti, kad Heideggerio transcendentalumo supratimas nèra toks pat, kaip Kanto. Antai Juozas Girnius, komentuodamas Heideggerio transcendentalumo samprata, teigia:

būtybès būtis, kaip liudija būties klausimo suvedimas i būties supratimo, arba būties „prasmès“ klausima, yra esmiškai transcendentalinè. Transcendentalija, kaip patyrimo galimybė, ir būtybès būtis, kaip patyrimo (empirinès būties) galimybè yra viena. Būtybès būtis nèra nei objektyvi būtybès prasme, nei subjektyvi empiriniam pažinimui priklausymo prasme. Ji yra grynai transcendentaline. <...> Kantui transcendencija yra grynas žmogaus pažinimas, Heideggeriui - žmogaus būtis. Jis kantiškają lygybę: būtis = transcendencija = grynasis protas, suveda i pirmesnę lytị: būtis = transcendencija = grynoji būtis, arba egzistencija (Girnius 1991: 149).

Žinoma, Girniaus vartojamos sąvokos nėra labai tikslios ir ne visai atitinka tai, apie ką kalbama šiame darbe. Tačiau galima sakyti, kad Girnius vis dèlto „užčiuopia" faktą jog transcendentalijos, Kantui būdamos kaip sąlygos pažinimui, Heideggerui tampa būvinio sąlyga: jeigu 
nèra buvimo, tuomet nèra ir būvinio. Kantas transcendentaliją suvokia epistemologiškai, o Heideggeris - ontologiškai. Tačiau tarp ju išlieka vienas, ir galbūt pats svarbiausias dalykas - transcendentalijos negali būti išsakytos arba, kitaip sakant, transcendentalija neturi apibrèžimo, nes ji Kantui yra sąlyga, o Heideggerui - pagrindas.

\section{Buvimo \\ kaip transcendentalijos "apibrèžimas"}

Laikantis nuostatos, kad buvimas yra transcendentalija, kuri yra būvinio „yra“ sąlyga ir pagrindas, prieinama prie išvados, kad buvimas negali turèti aiškaus apibrèžimo. Laikui ir erdvei Kanto filosofijoje būnant apriorinemis juslumo formomis, šių transcendentalijų aprioriškumas neleidžia jų apibrèžti, kadangi erdvè ir laikas yra sąlygos, kurios leidžia ką nors apibrěžti. Pvz., kalbėdamas apie erdvę Kantas teigia, kad „erdvė yra būtinas apriorinis teiginys, sudarantis visu išoriniu stebejimų pagrindą. <...> Negalima įsivaizduoti, kad nėra erdvès, nors visiškai galima įsivaizduoti, kad joje neaptinkama objektu“ (Kantas 1982: 76). Erdvė yra transcendentalinè sąlyga todèl, kad žmogus daiktus kaip reiškinius pažista tik dèl erdvès ir pats daiktas gali reikštis tik erdveje, nes esant ne-erdvẻje paties reiškimosi (objekto pasirodymo subjektui) neivvyktu, kadangi reiškinys turi turèti vieta, kurioje galètų reikštis, o žmogus tik ir gali pažinti tai, kaip objektas jam pasirodo.

Lygiai taip pat yra ir dèl buvimo. Heideggeriui teigiant, kad „už šios bend- riausios sąvokos „buvimas“ reikšmių srities, griežtai kalbant, nebėra nieko, kuo remiantis taptų įmanomas jos tolesnis "apibrèžimas". <...> Buvimo sąvoka yra galutinè" (Heidegger 2004: 59), pagrindžiamas faktas, jog buvimas negali būti apibrèžiamas lygiai taip pat, kaip Kanto laikas ir erdvè. Taip buvimo kaip transcendentalijos sąvoka igauna aprioriškumą, kadangi ji visuomet yra duota iš anksto; jeigu būvinys "yra“, tai tik dèl to, kad yra buvimas. Kaip sako Heideggeris, „,kai tik žodis „,buvimas“ pasiekia mūsų ausį, mes pareiškiame, kad negalime issivaizduoti, kas pasirodo už šios sąvokos, nes ją vartodami, apie ją nemąstome" (Heidegger 1998: 337). Ši Heideggerio mintis yra teisinga, nes visus būvinius „lydintis“ buvimas yra apriorinès kilmès sąlyga, kuri teikia galimybę išsakyti, pa(si)rodyti patị būvinį. Nesant buvimo, joks būvinys negali būti apmąstytas, nes buvimas kaip pagrindas eina kartu su kiekvienu būviniu.

Žinoma, išvada, kad buvimui neįmanoma suteikti apibrèžimo dèl šios sąvokos transcendentalumo, sukuria problemą. Jeigu apie buvimą kaip transcendentaliją negalima pasakyti nieko daugiau, tik kad ji yra būvinio "yra“ sąlyga, tai galbūt iš viso neverta net kalbèti apie ši ontologinès skirties nari. Bet laikantis Gadamerio minties, jog „kad problema būtų filosofinè, ji turi būti neišsprendžiama. Tai reiškia, ji turi būti tokia plati ir tokia gili, kad iškiltų kas kartą iš naujo, nes joks imanomas sprendimas negali su ja galutinai susidoroti" (Gadamer 1999: 113), galima sakyti: buvimo kaip transcendentalijos problema yra tikra filosofinè (ontologinè) problema. 


\section{BÜVINYS KAIP KÜRINYS}

\section{Buvinio kontingentiškumas}

Nagrinëjant Dievo kaip Būties sąvoką buvo prieita prie išvados, kad Dievas negali būti apibrèžiamas bendrinèmis kategorijomis, kadangi Dievo esmè yra egzistencija. Dievas yra actus purus, o tai neleidžia Dievui suteikti jokiu papildomu predikatų. Dèl to, kad Dievas egzistuoja su būtinumu ir tik jis vienas yra toks, visi būviniai egzistuoja ne su būtinumu, t. y. yra kontingentiški. Žinoma, būvinio kontingentiškumas nurodo, kad turi būti kažkas, kas egzistuoja būtinai, nuolatos ir yra begalinis (kaip paaiškëjo anksčiau, toks yra Dievas), o kažkas yra nebūtinas, laikinas ir baigtinis. Kaip pažymi Dunsas Scotas, „iki „būvinys“ yra padalintas i dešimt kategoriju, jis yra padalintas i begalinį ir baigtinį" (Scotus 1987: 2). Nors tai ontoteologinè nuostata (kadangi Dievas laikomas būviniu), bet Scotas pasako ši tą teisinga: Dievui būnant begaliniu, o būviniui - baigtiniu, tas, kas yra baigtino, reikalingas pagrindimo. Laikantis nuostatos, kad Dievas yra visa ko Kūrèjas, Dievas ir yra Tas, kuris būviniui duoda egzistenciją. Negalèdami žinoti tikslios priežasties, kodèl Dievas ką nors kuria, turime prieiti išvadą kad būvinio gali ir nebūti. Vadinasi, jis yra kontingentiškas.

Žinoma, galima manyti, kad visi būviniai egzistuoja su būtinumu, ir taip sakyti, kad Dievas neturi būti su būtinumu. Tačiau teisus yra Avicena, kurio minti cituoja Scotas, jog "tie, kurie neigia, kad kai kurie būviniai yra kontingentiški, turètų būti palikti kankinimams iki tol, kol jie supras, kad jie gali būti ir nekankinami“ (ten pat: 9). Kitaip sakant, būvinio kontingentiškumas iškyla iš tokio samprotavimo: jeigu aš galiu šiuo metu sèdèti prie stalo, tai kartu aš galiu ir nesèdèti prie stalo ir daryti ką nors kita; šis darbas, kuri dabar rašau, gali būti ir nerašomas. Mąstant nuosekliai iki pabaigos, prieinama prie išvados, jog faktas, kad aš esu, yra nebūtinas, kadangi manęs gali ir nebūti. Nebūdamas savo paties priežastis, turiu ieškoti to, kas yra mano priežastis. Nuosekliai judant tokiu keliu, turi būti prieinama prie išvados, kad Dievas yra tas, kuris man duoda buvimą, o pats Dievas egzistuoja su būtinumu, t. y. nereikalingas priežasties.

Tokia mąstymo eiga yra aristotelinè ${ }^{11}$. Kaip sako Maceina, „Aristotelis yra èjęs nuo atskiru reiškinių judejjimo prie pirmojo nejudančiojo judintojo: kaip kiekvienas judąs daiktas nurodo i kitą kaip savo judintoją, taip lygiai vieno reiškinio prasmė nurodanti i kitą kaip savo ịprasmintoją“ (Maceina 1976: 128). Pakeisdami judejimo principą egzistavimo principu, mąstymo padedami judame prie to, kas duoda egzistavimą būviniui ir kieno toji egzistencija yra būtina, nes būvinio egzistencija nèra būtina. Taip parodoma, kad bet koks būvinys, kuris yra ne Dievas, yra kontingentiškas, kadangi jis nèra actus purus, o susideda iš akto ir potencijos. Nors būvinys ir gali būti aktualiai, bet jo egzistencija yra neprivaloma, kadangi Dievas kaip Kūrëjas kuria tokius aktus, kurie turi ir potencialumą, t. y. galimybę būti ir nebūti. Tokius būvinius Kuraitis netgi laiko pagrindiniu ontologijos objektu. Jis sako, 
kad „pirmuoju, pagrindiniu ontologijos objektu yra realiai egzistuojančios, iš akto ir potencijos susidedančios esybès" (Kuraitis 1933: 9). Kadangi būvinys visados yra duotas pirmiausia, nuo jo ontologija ir turètu prasidèti. Tačiau dèl to, kad būvinio sąvoka šiame darbe suprantama tik kaip viena iš triju ontologiniu skirties nariu, tokio Kuraičio ontologijos objekto supratimo galima nesilaikyti, nes pirmiausia reikèjo išnagrinèti pačią būvinio atsiradimo priežasti (Dievą) ir ta, kas yra sąlyga būvinio „yra“ (buvimo).

Verta pažymèti, kad tomistinè perskyra tarp Ipsum Esse ir habens esse būvinio kontingentiškumo klausimu taip pat yra svarbi. Jeigu Dievas turi būti suprastas kaip Ipsum Esse, o visa kita kaip habens esse, tai būvinys ir yra habens esse ${ }^{12}$. Vadinasi, Dievas yra tas, iš kurio būvinys gauna buvimą. Žinoma, Dievo, kaip to, kuris duoda būviniui buvima, kūryba skiriasi, pvz., nuo gamtos kūrybos. Kadangi physis lygmenyje visa gali būti paaiškinama priežasties - pasekmès lygmenyje, tai tokie dalykai kaip žmogaus augimas yra tiesiog būtini. Tačiau Dievo kaip Kūrëjo atžvilgiu kūrimas turi būti suprastas taip, kaip sako Maceina: „visa tai, kas yra kilęs iš būtinybės, ir kas ja regimai išreiškia, vadiname daiktu. $\mathrm{O}$ visa, kas kilę iš laisvès ir ją regimai ịkūnija, vadiname kūriniu“" (Maceina 2000: 198). Čia tiesiog svarbu pažymèti, kad Dievas kaip Kūrèjas buvimą būviniui duoda laisvai. Kadangi Dievas negali būti ko nors apribotas, tai visa, ką Jis daro, tampa laisvès aktu, todèl ir pati būvinio kontingencija yra ne kas kita kaip Dievo laisvès apraiška.

Kadangi Dievas nėra apibrèžiamas, o būvinys yra, tai ir pati kalba gali būti tik apie būvini ir jokiu būdu ne apie Dievą. Kadangi Dievas apsireiškia pats, tai prasmingi sakiniai apie Dievą yra tik tokie, kuriuos Jis pats apie save pasako. Antai Rahneris, kalbėdamas apie Dievą kaip Paslapti, teigia, kad „krikščionis mažiau už ką kitą turi "galutinių" atsakymu, kurios jis galètų užantspauduoti ištardamas: „Na, dabar reikalas jau yra aiškus.“ Jis negali Dievo kaip konkretaus ir patikrinto punkto įtraukti i savo gyvenimo sąskaitą - jis tegali ji priimti kaip neaprépiamą paslaptį“ (Rahner 2008: 95). Negalint pasakyti nieko konkretaus apie Dieva, kalbëjimas apie Ji neprasmingas tol, kol Jis neapsireiškia. Betgi apie būvinius galima pasakyti ką nors prasminga, t. y. teisinga.

Galima tik pridurti, kad būtent žmogus kelia būties, buvimo ir būvinio klausimus. Minètosios „būties“, „buvimo“ ir „būvinio “ sąvokos kyla viena iš kitos ir nurodo viena kitą. Taip dvinare ontologinè skirtis tampa trinare, kadangi būties, buvimo ir būvinio sąvokų išsklaida duoda pagrindą tolesnei ontologijos plètrai. Todèl galima teigti, kad Grucès pasiūlymas, jog „formuojant pradines ontologijos mokslo sąvokas bei principus, negalima užmiršti sąsaju tarp svarstomų dalyku ir kitų faktų, nes tikrovejje niekas nefunkcionuoja atskirai“" (Grucè 1993: 46), yra teisingas.

\section{Literatūra}

1. Akvinietis T. 2009. Apie esini ir esmę. Vertė R. Plečkaitis. T. Akvinietis, Filosofiniu traktatų rinktine. Vilnius: Margi raštai: 5-38.
2. Aquino, S. T. de. De Potentia. Prieiga per internetą: http://www.corpusthomisticum.org/qdp7. html 
3. Aquino, S. T. de. Summa Theologiae. Prieiga per internetą: http://www.corpusthomisticum.org/ sth1003.html

4. Augustinas A. 2001. Apie laisvaji sprendima. Vertè O. Daukšienè. Vilnius: Katalikų pasaulis.

5. Capelle-Dumont P. 2010. Filosofija ir teologija Martino Heideggerio mąstyme. Vertè P. Aleksandravičius. Vilnius: Aidai.

6. Gadamer H.-G. 1999. Destrukcija ir dekonstrukcija. Vertè A. Sverdiolas. H.-G. Gadamer, Istorija. Menas. Kalba. Vilnius: Baltos lankos: 199-2009.

7. Gadamer H.-G. 1999. Sąvokų istorija kaip filosofija. Vertè A. Sverdiolas. H.-G. Gadamer, Istorija. Menas. Kalba. Vilnius: Baltos lankos: 109-121.

8. Gilson E. 1993. Christian Philosophy. Trans. by. A. Maurer. Toronto: Pontifical Institute of Mediaeval Studies.

9. Gilson E. 1960. Elements of Christian Philosophy. New York: Doubley\&Company Inc.

10. Gilson E.1940. Spirit of Mediaeval Philosophy. Trans. by. A. H. C. Downes. New York: Charles Scribers Sons.

11. Girnius J. 1991. Heideggerio egzistencialinès filosofijos pagrindai. J. Girnius, Raštai, t. I. Vilnius: Mintis: p. 135-195.

12. Grucè R. 1993. Ontologija. Logos 7: 41-56.

13. Heidegger M. 2000. Introduction to Metaphysics. Trans. by G. Fried and R. Polt. New Haven: Yale University Press.

14. Heidegger M. 1997. Kant and the Problem of Metaphysics. Trans. by R. Taft. Indiana: Indiana University Press.

15. Heidegger M. 1998. Pathmarks. Trans. by W. McNeil. Cambridge: Cambridge University Press.

\section{Nuorodos}

1 Plato, Sophist. Trans. by. B. Jowett. Plato Dialogues of Plato. Vol. IV. London: Oxford University Press, 1892, p. 373-374, 244a.

2 Ten pat, p. 395, 260 b.

3 Verta atkreipti dėmesi, kad Dievo ir Pirmojo Judintojo supratimas negali būti tapatus. Kadangi Dievas krikščioniškojoje tradicijoje pirmiausia suprantamas kaip Asmuo, kaip Kūrëjas ir tas, kas yra anapus, o Aristoteliui Pirmasis Judintojas pirmiausia reikalingas paaiškinti kitimo priežastį, tai prasmingas Phillippe'o Cap-
16. Heideggeris M. 2004. Metafizikos izvadas. Vertė T. Sodeika. Žmogus ir Žodis 4: 45-63.

17. Kantas I. 1982. Grynojo proto kritika. Vertè R. Plečkaits. Vilnius: Mintis.

18. Kuraitis P. 1931. Ontologija, t. I. Kaunas: Šviesa.

19. Kuraitis P. 1933. Ontologija, t. II. Kaunas: Šviesa.

20. Kuraitis P. 1990. Ontologija. Filosofijos raštu rinktine. Oak Lawn: Ateitis: 103-134.

21. Maceina A. 2000. Filosofijos kilmè ir prasmè. Raštai, t. VI. Vilnius: Mintis, 2000: 7-335.

22. Maceina A. 1976. Religijos filosofija. Putnam: Krikščionys Gyvenime.

23. Maceina A. 1990. Jobo drama. Raštai, t. III. Vilnius: Mintis: 423-605.

24. Oniščik Marija 2004. Egzistencinio tomizmo ižvalgu reikšmė analitinei filosofijai. Soter 42: 187-198.

25. O'Rourke F. 1992. The Gift of Being: Aquinas and Heidegger. In At the Heart of the Real. Philosophical essays in Honour of the Most Reverend Desmond Connell, Archibishop of Dublin. Ed. By Fran O'Rourke. Dublin: Irish Academic Press: 309-338.

26. Plato. 1892. Sophist. The Dialogues of Plato, Vol. IV. Trans. by B. Jowett. London: Oxford University Press: 285-407.

27. Rahner K. 1994. Hearer of the Word. Trans. by J. Donceel. New York: Continuum.

28. Rahner K. 2008. Kodèl aš šiandien esu krikščionis? Vertė N. Šepetys. J. Ratzinger, H. U. Von Balthazar, K. Rahner, Kodèl aš šiandien dar esu krikščionis? Vilnius: Aidai: 91-107.

29. Scotus J. D. 1987. Concerning Metaphysics. Trans. by A. Wolter. Philosophical Writings. Indianapolis: Hackett Publishing Company: 1-12.

30. Vyčinas V. 2002. Mano gyvenimas ir Minties raida. Raštai, t. I. Vilnius: Mintis: 11-30.

pelle-Dumonto teiginys, kad „Pirmojo Judintojo tematika neišsemia viso, ką nurodo žodis

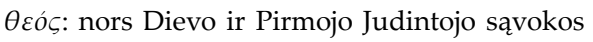
susitinka ,principo“ ir „visų dalykų priežasties" būtinumo apmąstyme, jų negalima sutapatinti“ (Cappelle-Dumont 2010: 104).

4 Pranas Kuraitis, Ontologija, t. I, p. 108.

5 Bet kurio atveju pirmiausia šiame darbe laikantis krikščioniškosios pozicijos, Dievas suprantamas kaip tas, kuris duoda būviniui egzistenciją. Kitaip sakant, tik dèl to, kad Dievas duoda eg- 
zistenciją būviniui, galima pasakyti, kad būvinys yra, nes, kaip sako šv. Augustinas, „,kiekviena substancija yra Dievas arba iš Dievo" (Augustinas 2001: 335).

6 Aquino, Sancti Thomae de. De Potentia, q. 7, a. 2, ad. 1. Prieiga per internetą: http://www.corpusthomisticum.org/qdp7.html

7 Aquino, Sancti Thomae de. De Potentia, q. 7, a. 2, ad 8. Prieiga per internetą: http://www.corpusthomisticum.org/qdp7.html

${ }^{8}$ Jau šioje vietoje būtu galima sakyti, kad tai žymi ontologinę skirtị tarp būvinio ir Būties, kuri tomistinëje filosofijoje tampa akivaizdi, kadangi ens ir esse žymi skirtingus dalykus.

9 Aquino, Sancti Thomae de, Summa Theologiae, I, q. 3, a. 4, ad 2. Prieiga per internetą: http://www. corpusthomisticum.org/sth1003.html

${ }^{10}$ Pranas Kuraitis, Ontologija, t. I, p. 152.

11 Tai ne tik aristotelinis mąstymo kelias, bet ir vienas iš Akviniečio „kelių“ Dievo buvimui "irodyti“.

12 Etienne Gilson, Elements of Christian Philosophy, p. 177. 